\title{
Short Communication: Genetic diversity among Fusarium isolates from cereals in Iran assessed using RAPD marker
}

\author{
SARA SIAHPOUSH", MOSTAFA DARVISHNIA ${ }^{\circ \bullet}$ \\ Department of Plant Protection, Lorestan University, P.O. Box 465, Khorramabad, Iran. Tel. +98-9396610280, \\ "email: s_9162@yahoo.com, ” mdarvishnia44@yahoo.com \\ Manuscript received: 16 July 2018. Revision accepted: 29 December 2018.
}

\begin{abstract}
Siahpoush S, Darvishnia M. 2019. Short Communication: Genetic diversity among Fusarium isolates from cereals in Iran assessed using RAPD marker. Biodiversitas 20: 292-296. Fusarium species cause important disease on many crops including cereals, and accurate identification and then proper management of this disease will be helpful to reduce economic losses. In this paper, 13 Fusarium isolates from root and crown of cereals in western Iran were identified by morphological and molecular methods. Sequencing of translation elongation factor 1-alpha revealed 8 species as follows: Fusarium acuminatum, F. avenaceum, F. culmorum, F. equiseti, $F$. proliferatum, $F$. reticulatum, $F$. solani, and $F$. tricinctum. Species diversity was analyzed by random amplified polymorphic DNA (RAPD). Four primers were used as Rfu9, Rfu10, Rfu23, and Rfu25 which all of them produced distinct and reproducible bands. A dendrogram was developed by UPGMA. Generated polymorphic bands were observed in all 13 different species by 4 primers. Rfu9 by 13 bands and Rfu 23 by 10 ones, produced the most and the least bands respectively. Genetic similarity coefficient was between $0.00-$ 0.9. RAPD analysis showed that these isolates were genetically varied and two clusters were formed with Fusarium isolates.
\end{abstract}

Keywords: Fusarium, genetic diversity, RAPD, translation elongation factor 1-alpha, UPGMA

\section{INTRODUCTION}

Cereals are the main crops in Asia as human and livestock nutrition. Unfortunately, some destructive diseases such as Fusarium root rot cause many economic damages to these crops. Fusarium head blight is one of the most important diseases all over the world (Yli-Mattila et al. 2009). Latiffah et al. (2007) reported Fusarium as one of the main pathogens in plants. Root rot disease is a common problem found in almost all of cereal crops all over the world. Previous studies showed that Fusarium species were commonly associated with crown disease. Fusarium root, crown, and root rots cause patches of wheat to die prematurely, resulting in areas of whiteheads within a field. Infected plants are typically brown at the base and have poor root development.

Due to limitations of morphological methods to identify Fusarium species, molecular markers based on polymerase chain reaction (PCR) are an extended choice (Sabir 2006). Molecular markers especially Random amplified polymorphic DNA (RAPD) (Gupta et al. 2009) and Amplified Fragment Length Polymorphisms (AFLP) (Niessen 2007) are used to differentiate fungal taxa (Steinkellner et al. 2008).

Random Amplified Polymorphic DNA analysis is a fast, PCR-based way of genetic typing based on genomic polymorphisms (Abdel-Satar et al. 2003; Ingle et al. 2009), bacteria and plants (Singh et al. 2011). This technique is used for genetic variability detection (Sabir 2006) and is easy and rapid for evaluation of genetic variation (Niessen 2007; Gupta et al. 2009). Other analysis methods are Amplified Fragment Length Polymorphism (AFLP) and Restriction Fragment Length Polymorphisms (RFLP) based on selective amplification of DNA restriction fragments (Vos et al. 1995; Chulze et al. 2000).

Genetic polymorphism between isolates of $F$. solani was studied by Gupta et al. (2009) in India by RAPD. Smith et al. (2001), Arif et al. (2011), Niessen (2007), Gupta et al. (2009), and Bonde et al. (2013) reported genetic variation among Fusarium isolates by RAPD marker.

The aim of this study was determination of genetic diversity of some Fusarium species by RAPD-PCR.

\section{MATERIALS AND METHODS}

\section{Sample collection}

The study was carried out in western Iran, Lorestan fields (Figure 1), during May to October of 2016. The samples were isolated from root and crown of Poaceae species including wheat, barley, corn, and some grass species showing symptoms of root and crown rot. 

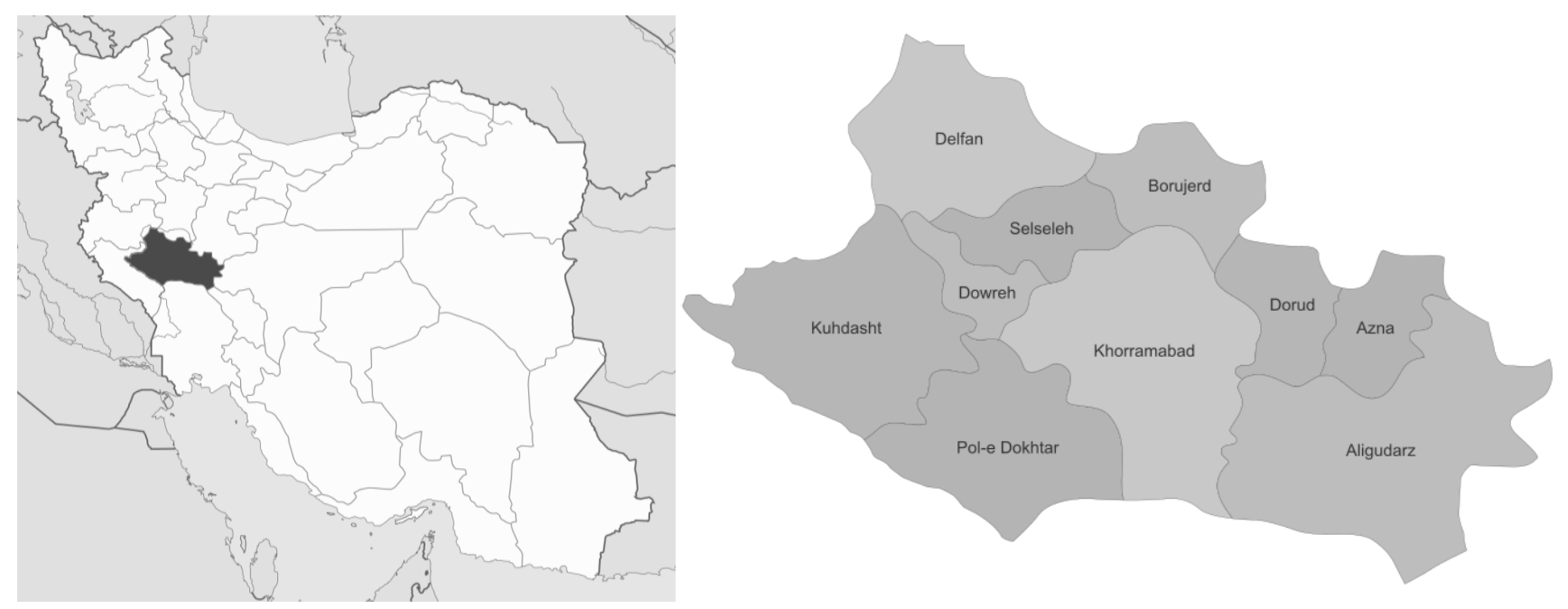

Figure 1. Study site: Lorestan fields, Iran

\section{Procedures}

\section{Fusarium isolation}

Nash and Snyder (1962) described a selective medium for Fusarium species with a peptone base and pentachloronitrobenzene (PCNB) as a fungal inhibitor. This medium was highly selective for some Fusarium species, therefore the isolates were cultured on NashSnyder/PCNB and also dichloro-chloramphenicol-peptone agar (DCPA) media, followed by incubation at $28 \mathrm{C}^{\circ}$ for 7 days (Andrews and Pitt 1986). After about 1week incubation, Fusarium colonies emerged from plant materials. A pure culture obtained from a single conidium or hyphal tip of each isolate was inoculated on Potato Dextrose Agar (PDA) (Merck, Germany) for examination of colony color and growth rate at $25 \mathrm{C}^{\circ}$ (Burgess et al. 1994). For microscopic observations, all isolates were transferred to carnation leaf agar (CLA), synthetic nutrient agar (SNA), $\mathrm{KCl}$ plates and sterile distilled water tubes and incubated under $12 \mathrm{~h}$ alternating light at $25 \pm 2{ }^{\circ} \mathrm{C}$ for $1-2$ weeks (Nelson et al. 1983). All isolates produced typical spores including macro and microconidia and chlamydospores.

\section{Identification of isolates}

Fusarium isolates were identified based on general characteristics of the colony (morphology of microconidia, macroconidia, conidiophores, chlamydospore) by using Fusarium diagnostic keys (Gerlach and Nirenberg 1982; Nelson 1983; Burgess et al. 1994; Leslie and Summerell 2006). Observations were made using trinocular brightfield microscope (Olympus BX41).

\section{DNA extraction}

Molecular identification was performed by examining DNA sequences obtained from translation elongation factor 1-alpha (TEF). Mycelial plugs were transferred from PDA to $50 \mathrm{~mL}$ of potato dextrose broth (PDB). Cultures were grown for $5 \mathrm{~d}$ at $25 \pm 2{ }^{\circ} \mathrm{C}$ on a rotary shaker at 100 r.p.m. with $8 \mathrm{~h}$ of light every day. Mycelia were collected on to Whatman filter paper using a vacuum pump, rinse and remove excess liquid by placed them between layers of dry filter paper, then were lyophilized at $-20^{\circ} \mathrm{C}$.

Genomic DNA was extracted using the established CTAB method (Wu et al. 2001). Freeze-dried mycelium was ground to a fine powder in liquid nitrogen using a precooled pestle and was transferred to microtube. A $1000 \mu \mathrm{L}$ of extraction buffer (CTAB 1\% (w/v), EDTA $10 \mathrm{mM} \mathrm{pH}$ 8.0, Tris- $\mathrm{HCl} 100 \mathrm{mM} \quad \mathrm{pH} \quad 8.0, \quad \mathrm{NaCl} \quad 0.7 \quad \mathrm{M}$, mercaptoethanol $0.2 \%$ ) was added. After incubation at $65^{\circ} \mathrm{C}$ for $30 \mathrm{~min}$, and $40^{\circ} \mathrm{C}$ for $10 \mathrm{~min}$, DNA was extracted with an equal volume of phenol: chloroform: isoamyl alcohol (25:24:1) and precipitated using $-20{ }^{\circ} \mathrm{C}$ isopropanol $(1: 1)$. Precipitated DNA was washed with $70 \%$ ethanol, dried and suspended in TE buffer (Tris-hydrochloride buffer $-10 \mathrm{mM}$ Tris- $\mathrm{HCl} \mathrm{pH}$ 8.0, $0.1 \mathrm{mM}$ EDTA). Finally, the DNA was dissolved in $50 \mu \mathrm{L}$ of pure water and was kept at $-20^{\circ} \mathrm{C}\left(\mathrm{O}^{\prime}\right.$ Donnell et al. 1998).

\section{Amplification of a partial sequence of TEF}

Amplification was performed in a total volume of 25 $\mu \mathrm{L}$ (O'Donnell and Cijelnik 1997). PCR amplification of EF-1 $\alpha$ was carried out using a pair of primers EF1(5'ATGGGTAAGGA(A/G)GACAAGAC-3') and EF2 (5'GGA(G/A)GTACCAGT(G/C) ATCATGTT-3') primers (O'Donnell et al. 1998) in thermocycler with initial denaturing step of $5 \mathrm{~min}$ at $94^{\circ} \mathrm{C}$ followed by 35 cycles $(35$ $\mathrm{s}$ at $94^{\circ} \mathrm{C}, 55 \mathrm{~s}$ at $52^{\circ} \mathrm{C}$ and $2 \mathrm{~min}$ at $72^{\circ} \mathrm{C}$ ) finished by a final extension step at $72^{\circ} \mathrm{C}$ for $10 \mathrm{~min}$. Electrophoresis of PCR products was performed on $1.5 \%$ agarose by gel red for staining. The condition was $100 \mathrm{v}$ for $1 \mathrm{~h}$. Then produced bands were visualized in a UV-transilluminator and photography was carried out by Gel Doc.

\section{RAPD analysis}

Thirteen different Fusarium isolates were subjected to RAPD-PCR (Table 1). Extracted DNA was amplified by 4 selective primers (Bonde et al. 2013) (Table2). PCR conditions were: an initial denaturation step at $94^{\circ} \mathrm{C}$ for 2 min, 35 cycles of $94^{\circ} \mathrm{C}$ for $30 \mathrm{~s}, 40^{\circ} \mathrm{C}$ for $60 \mathrm{~s}, 72^{\circ} \mathrm{C}$ for 2 min and a final extension at $72^{\circ} \mathrm{C}$ for $5 \mathrm{~min}$. Total volume 
of reaction was $25 \mu \mathrm{L}$ contained $2.5 \mu \mathrm{L}$ of PCR buffer, 1 $\mu \mathrm{L} \mathrm{MgCl}_{2} 50 \mathrm{mM}, 0.75 \mu \mathrm{L}$ of dNTP mixture $(200 \mu \mathrm{mol}$ each), $2 \mu \mathrm{L}$ of sample DNA (10 ng), $2 \mu \mathrm{L}$ of primers (10 Pmol $/ \mu \mathrm{l}), 0.5 \mu \mathrm{L}$ of Taq polymerase and $16.25 \mu \mathrm{L}$ sterile distilled water. PCR products were electrophoresed on $1.5 \%$ agarose gel including safe stain, then they were observed using Gel Documentation.

\section{Data analysis}

Polymorphic RAPD markers were manually scored as binary data with presence as "1" and absence as "0". Cluster analysis was performed employing the (UPGMA) method (Sneath and Sokal 1973) using NTSYSpc version 2.2 (Exeter Software Co. New York).

\section{RESULTS AND DISCUSSION}

There were 13 Fusarium isolates from cereals in western Iran were identified in this study, using identification keys of Gerlach and Nirenberg (1982), Nelson (1983), Burgess et al. (1994) and Leslie and Summerell (2006) (Table 3).

Table 1. Fusarium isolates in RAPD analyses

\begin{tabular}{ll}
\hline & Isolate \\
\hline 1 & SPF300 \\
2 & SPF507 \\
3 & SPF516 \\
4 & SPF292 \\
5 & SPF341 \\
6 & SPF441 \\
7 & SPF015 \\
8 & SPF054 \\
9 & SPF548 \\
10 & SPF261 \\
11 & SPF207 \\
12 & SPF501 \\
13 & SPF010 \\
\hline
\end{tabular}

Table 2. Primers for RAPD analysis (Bonde et al. 2013)

\begin{tabular}{ll}
\hline Primers & Sequences (5'-3') \\
\hline RFu9 & CCTGGGTGCA \\
RFu10 & CCTGGGTGAC \\
RFu23 & CCGGCCATAC \\
RFu25 & CCGGCTGGAA \\
\hline
\end{tabular}

Table 3. Identified Fusarium species by morphological characters

\begin{tabular}{ll}
\hline Isolate & Species \\
\hline SPF300 & Fusarium acuminatum \\
SPF507 & F. acuminatum \\
SPF516 & F. avenaceum \\
SPF292 & F. culmorum \\
SPF341 & F. equiseti \\
SPF441 & F. proliferatum \\
SPF015 & F. proliferatum \\
SPF054 & F. proliferatum \\
SPF548 & F. proliferatum \\
SPF261 & F. reticulatum \\
SPF207 & F. solani \\
SPF501 & $F$. solani \\
SPF010 & F. tricinctum \\
\hline
\end{tabular}

Molecular characterization was used for verification of the species based on the PCR amplified product of EF1 gene. Results of RAPD analysis in a13 isolates showed that all of 4 primers (RFu 9, RFu 10, RFu 23 and RFu 25) produced distinct and reproducible bands (Figure 2). The target amplified fragments were 1-3 kb. Results of UPGMA analysis of the RAPD data separated the species in two main clusters (Figure 3). A total of $85 \%$ of the isolates were in the first cluster in which two subclusters were observed. SPF015 and SPF548 showed genetic similarity of $\mathrm{GS}=70 \%$, isolates SPF341 and SPF054 showed very high genetic similarity of GS=83\%. SPF010 constituted one cluster branched from the first main cluster at level of $0.42 \%$. The second cluster consisted of two isolates of $F$. solani at the genetic similarity of $\mathrm{GS}=54 \%$. The results of the RAPD analysis showed diversity among the Fusarium spp.

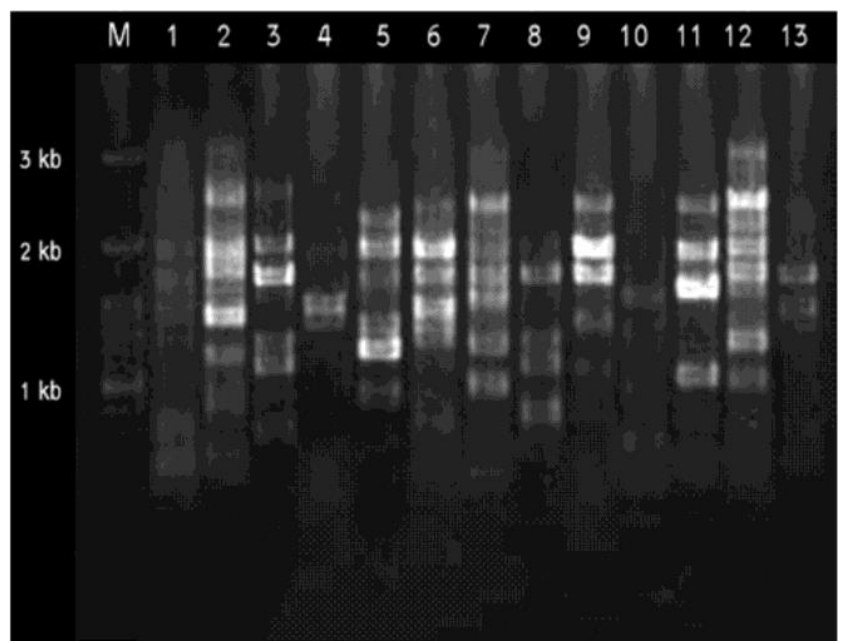

Figure 2. RAPD patterns on $1.5 \%$ agarose gel of amplified fragments generated from 13 Fusarium isolates with primer $\mathrm{RFu}-$ 23. M, DNA marker $(1 \mathrm{~kb})$.

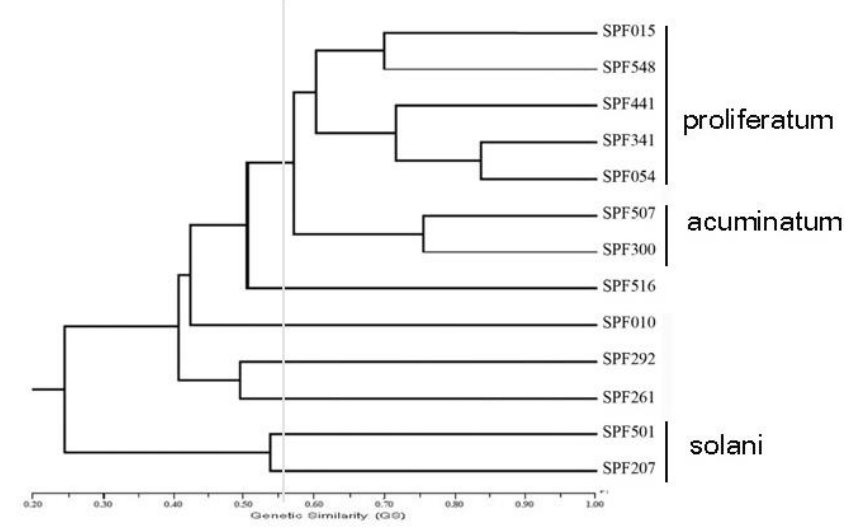

Figure 3. UPGMA dendrogram of 13 isolates of Fusarium isolates based on RAPD-PCR 
Genetic diversity plays an important role in diseases management programs. Understanding the nature of variation of pathogens is necessary through the use of resistant cultivars. Diversity determination methods are mostly used in various studies and results provide beneficial information for future populations (Thaware et al. 2017).

RAPD analysis for wide range of plants, fungi, and bacteria in many scientific fields is used to uncover genetic variation of closely related taxa. In plant pathology, this method was used to differentiate Fusarium species by many researchers. Ingle and Rai (2011) studied Fusarium species variation by RAPD. Thaware et al. (2017) used RAPD method to specify variability of some Fusarium isolates in India. Some races of $F$. oxysporum f.sp. vasinfectum were differentiated by RAPD (Assigbetse et al. 1994). Arici and Koc (2010) estimated genetic variation among isolates of Fusarium graminearum and Fusarium culmorum from wheat in Turkey by RAPD-PCR. Genetic diversity of $F$. oxysporum f.sp. lentis population was determined by some molecular markers including RAPD by Al-Husein et al. (2017) in Syria. Fusarium species isolated from eggplant in Turkey were classified on the basis of RAPD by Baysal et al. (2010). Our results showed genetic diversity in Fusarium isolates from cereals in Iran. These isolates were identified by morphological features and then by sequencing of partial translation elongation factor 1-alpha. This DNA coding region was used to identify Fusarium species. O'Donnel et al. (1998) revealed that unlike RFLP which was insufficient to distinguish species in Gibberella fujikuroi complex, RAPD could distinguishes them very well. El-Fadly et al. (2008) identified some Fusarium species and diversity between them by TEF sequence and RAPD respectively. The aim of this work was to determine whether our Fusarium isolates have genetic diversity. Results showed that amplified DNA bands can use reproducible to differentiate Fusarium isolates and this agrees with the results of Balmas et al. (2010), Ingle and Rai (2009), Gupta et al. (2009) and Nagarajan et al. (2004). Gherbawy (1999) in research, used RAPD marker to study genetic diversity among 20 isolates of Fusarium. They used data generated from RAPD banding pattern for the UPGMA analysis and found that there were genetic variations in different isolates of Fusarium (Abd-Elsalam et al. 2003).

If isolates from these divergent species interbreed, there will be the potential for the production of new genotypes that carry novel combinations of genes for pathogenicity. Therefore, identification of additional isolates is important in the future.

\section{REFERENCES}

Abd-Elsalam KA, Schnieder F, Asran-Amal A et al. 2003. Intra-species genomic groups in Fusarium semitectum and their correlation with origin and cultural characteristics. J Plant Dis Prot 10: 409-418.

Abdel-Satar MA, Khalil MS, Mohmed IN, et al. 2003. Molecular phylogeny of Fusarium species by AFLP fingerprint. Afr J Biotechnol 2(3): 51-55.
Al-Husein NH, Hamwieh A, Ahmed S and Bayaa B. 2017. Genetic diversity of Fusarium oxysporum f.sp. lentis population affecting lentil in Syria. J Phytopathol 165 (5): 306-312.

Andrews S, Pitt JI. 1986. Selective medium for the isolation of Fusarium species and dematiaceous Hyphomycetes from cereals. Appl Environ Microb 51: 1235-1238.

Arici SE, Koc NK. 2010. Genetic variation among isolates of Fusarium graminearum and Fusarium culmorum from wheat in Adana Turkey. Pak J Biol Sci 13(3): 138-142.

Arif M, Pani DR, Zaidi NW, Singh US. 2011. PCR-based identification and characterization of Fusarium sp. associated with mango malformation. Biotech Res Intl. Article ID 141649, 6 pages.

Assigbetse KB, Fernandez D, Dubois MP, Geiger JP. 1994. Differentiation of Fusarium oxysporum f. sp. vasinfectum races on cotton by Random amplified polymorphic DNA (RAPD) analysis. Phytopathol 84: 622-626.

Balmas V, Migheli Q, Scherm B, Garau P. 2010. Multilocus phylogenetics shows high levels of endemic fusaria inhabiting Sardinian soils (Tyrrhenian Islands). Mycologia 102(4): 803-812.

Baysal O, Siragusa M, Gumrukcu E, et al. 2010. Molecular characterization of Fusarium oxysporum f. melongenae by ISSR and RAPD markers on eggplant. Biochem Genet 48(5-6): 524-537.

Bonde SHR, Gade AK, Rai MK. 2013. Genetic diversity among fourteen different Fusarium species using RAPD marker Biodiversitas 14(2): 55-60.

Burgess LW, Summerell BA, Bullock S et al. 1994. Laboratory manual for Fusarium research. University of Sydney/Royal Botanic Gardens, Sydney, Australia.

Chulze SN, Ramirez ML, Torres A, Leslie JF. 2000. Genetic Variation in Fusarium Section Liseola from No-Till Maize in Argentina. Appl Environ Microb 66(12): 5312-5315.

El-Fadly GB, El-Kazzaz MK, Hassan MAA, El-Kot GAN. 2008. Identification of some Fusarium spp. using RAPD-PCR technique. Egypt J Phytopathol 36(1-2): 71-80.

Gerlach W, Nirenberg H. 1982. The Genus Fusarium, a Pictorial atlas. Mitt. Biol. Bundesanst. Land-und Forstwirtsch. Berlin Dahlem.

Gherbawy YAMH. 1999, RAPD profile analysis of isolates belonging to different formae speciales of Fusarium oxysporum, Cytologia 64:269276.

Gupta VK, Misra AK, Gaur R, et al. 2009. Studies of genetic polymorphism in the isolates of Fusarium solani. Austr J Crop Sci 3:101-106.

Ingle AP, Karwa A, Rai MK, Gherbawy Y. 2009. Fusarium: Molecular detection, mycotoxins and biocontrol. In: Gherbawy Y, Mach R, Rai M (eds). Current Advance in Molecular Mycology. Science Publishers Inc. Enfield, New Hampshire.

Ingle AP, Rai MK. 2011. Genetic Diversity among Indian phytopathogenic isolates of Fusarium semitectum Berkeley and Ravenel. Adv Biosci Biotech 2: 142-148.

Latiffah Z, Zariman M, Baharuddin S. 2007. Diversity of Fusarium species in cultivated soils in Penang. Malay J Microb 3: 27-30.

Leslie JF, Summerell BA. 2006. The Fusarium laboratory manual. 1st ed. Blackwell Pub. Ames, Iowa.

Nagarajan G, Nam MH, Song JY et al. 2004. Genetic variation in Fusarium oxysporum f. sp. fragariae populations based on RAPD and rDNA RFLP analyses. P1 Pathol J 20: 264-270.

Nelson PE, Toussoun TA, Marasas WFO. 1983. Fusarium species: an illustrated manual for identification. Pennsylvania State University Press, University Park.

Niessen L. 2007. PCR based diagnosis and quantification of mycotoxinproducing fungi. Intl J Food Microb 119: 38-46.

O'Donnell K, Cigelnik E. 1997. Two divergent intragenomic rDNA ITS type within a monophyletic lineage of the fungus Fusarium are nonorthologous. Mol Phylogenet Evol 7: 103-116.

O'Donnell K, Cigelnik E, Nirenberg HI. 1998. Molecular systematics and phylogeography of the Gibberella fujikuroi species complex. Mycologia 90: 465-493.

Sabir SM. 2006. Genotypic identification for some Fusarium sambucinum strains isolated from Wheat in Upper Egypt. World J Agri Sci 2(1): 610.

Singh M, Chaudhuri I, Mandal SK, Chaudhuri RK. 2011. Development of RAPD Markers linked to Fusarium Wilt Resistance Gene in Castor Bean (Ricinus communis L). Genet Eng Biotech J (Gebj-28): 1-8.

Smith SN, Decay JE, Hsui HW, et al. 2001. Soil-borne populations of Fusarium oxysporum f. sp. vasinfectum, cotton wilt fungus in California fields. Mycologia 93:737-743. 
Sneath P, Sokal R. 1973. Numerical Taxonomy. Freeman, San Fransisco. Steinkellner S, Mammerler R, Vierheilig H. 2008. Germination of Fusarium oxysporum in root exudates from tomato plants challenged with different Fusarium oxysporum strains. Eur J Plant Path 122: 395401.

Thaware DS, Kohire OD, Gholve VM. 2017. Cultural, morphological and molecular variability of Fusarium oxysporum f.sp. ciceri isolates by RAPD method. Intl J Cur Microb Appl Sci 6(4): 2721-2734.
Vos P, Hogers R, Bleeker M et al. 1995. AFLP: a new technique for DNA fingerprinting. Nucl Acids Res 23: 4407-4414

Wu ZH, Wang TH, Huang W, Qu YB. 2001. A simplified method for chromosome DNA preparation from filamentous Fungi. Mycosystema 20: 575-577

Yli-Mattila T, Gagkaeva T, Ward TJ, et al. 2009. A novel Asian clade within the Fusarium graminearum species complex includes a newly discovered cereal head blight pathogen from the Russian Far East. Mycologia 101 (6): 841-852. 